FACTA UNIVERSITATIS

Series: Economics and Organization Vol. 17, No 4, 2020, pp. 317 - 328

https://doi.org/10.22190/FUEO200612023J

Original Scientific Paper

\title{
THE IMPACT OF BRAND VALUE ON MARKET PERFORMANCE INDICATORS OF HIGH-TECHNOLOGY ENTERPRISES
}

\author{
UDC 003.65
}

\author{
Milica Jovanović1, Bojan Krstić², Sandra Milanović1 \\ ${ }^{1}$ Innovation Center, University of Niš, Niš, Serbia \\ ${ }^{2}$ Faculty of Economics, University of Niš, Niš, Serbia
}

\begin{abstract}
Brand valuation gained in importance in the 1980s, when a difference between the price at which some enterprises are bought and their value, according to the balance sheet, was noticed. Brand value can be considered an intangible asset of an enterprise, whose impact on the market performance indicators must be taken into account. This paper examines the relationship between brand value and selected market performance indicators using correlation and regression analysis. The analysis is based on Interbrand data on brand value and annual reports of selected enterprises from high-technology sector. The sample included top 5 enterprises from high technology sector, whose corporate brands are on the list of the 100 most valuable brands, in all years of the analysed eight-year period (from 2012 to 2019). This paper discovered a statistically significant positive relationship between brand value and market performance indicators and that brand value positively influences those performances of high - technology enterprises. The focus of this study is on the following market performance indicators: market capitalization, Tobin's $Q$, market to book ratio and earnings per share. The research contributes to the field of brand value management and emphasizes the importance of investments in corporate branding process.
\end{abstract}

Keywords: brand value, market performance, market capitalization, Tobin's $Q$, market to book ratio, earnings per share

JEL Classification: M21, M31, M40

Received June 12, 2020 / Revised September 15, 2020 / Accepted September 28, 2020

Corresponding author: Sandra Milanović

University of Niš, Innovation Center, Univerzitetski trg 2, 18000 Niš, Serbia

E-mail: sandramilanovic89@yahoo.com

(๑) 2020 by University of Niš, Serbia | Creative Commons Licence: CC BY-NC-ND 


\section{INTRODUCTION}

For decades, the value of an enterprise has been expressed based on material, tangible resources, such as buildings, equipment and land. However, in the era of the knowledgebased economy, the importance of financial and physical resources is decreasing and intellectual/intangible resources are becoming increasingly important. Drucker (1994) has pointed out that the key to the enterprise's growth is the knowledge of not only employees but also other company stakeholders. The knowledge contained in the management structure of the company, business processes, information systems, patents, brands and other forms of intangible assets becomes a source of gaining and maintaining competitive advantage and improving business performance.

The brand valuation concept originates from the UK, from the early 1980s, due to several mergers, joint ventures and licensing. Primarily, the goal was to improve company management and create value for company stakeholders (Davidson, 1998). The history of brand valuation began in 1984, when the News Group included the valuation of publishing titles in its balance sheet and as a result, improved debt-to-equity ratio (Blackett, 1991). In the mid-1980s, companies realized the importance of the brand and the need for brand valuation, when a consulting firm, Interbrand, conducted the first brand valuation for Rank Hovis McDougall company. The goal of this company was to show the value of the brand in the balance sheet and thus improve the company takeover bid that was given (Seetharaman et al., 2001). In the late 1980s, many companies were sold at a price that is several times higher than the value of these companies, according to data from the balance sheet and other company's financial statements (Kapferer, 2012, p. 2). It was observed that for companies with recognizable brands, acquirers were willing to pay much more than the net value of those enterprise's assets. ${ }^{2}$ In this way, buyers have purchased already built customer opinions on products with the brand, which is a guarantee of future earnings. Brand value derives from a brand's ability to generate cash-flows in the long run for the enterprise that owns it.

There are many reasons why brand value plays an important role for modern companies that invest in intellectual resources, especially for companies whose business does not depend on fixed assets but human capital and other intangible resources. Such is the case with enterprises in the IT sector. Some of the reasons are the following: connection of the brand valuation model with the enterprise's business model, better allocation of resources, more successful management of the brand portfolio, merger and acquisition planning, tax planning, better communication with internal and external stakeholders of the company (especially with investors), better borrowing conditions, licensing and franchising (Brand Finance, 2000, p. 7). Therefore, different models of brand valuation have been developed. It can be divided into two groups - methods based on consumer perception and methods for determining the financial value of the brand (Krstić et al., 2014; Popović et al., 2015).

The aim of this paper is to indicate the relationship between brand value and market performance indicators. The growing concern for the influence of brand value was transferred to the high-technology sector as well, especially because this sector is characterised by companies with a significantly high value of brands. This paper should point out the importance of investing in the branding process and the importance of brand management

${ }^{2}$ For example, during that period, Nestlé bought Rowntree, Danone bought Nabisco's European business and Grand Metropolitan bought Pillsbury for prices that were significantly higher than the value of the tangible asset of the acquired enterprises, given that it was, in fact, a purchase of recognizable brands (Seetharaman et al., 2001). 
in enterprises from the high-technology sector. The research plays an important role because it demonstrates that, by investing in brand value, such companies can improve their market performance. This field of research is becoming increasingly important with increasing corporate investment in intangible assets by companies from the high-technology sector, while intangible assets are becoming dominant in the era of the knowledge economy.

The paper is structured into three parts. In the first part, a literature overview is given different understandings of the concept of brand value and brand equity and their differences. The theoretical aspect of the relationship between brand value and selected market performance indicators is also presented. The second section includes the methodology of the research and the last part gives the discussion of the study results.

\section{LITERATURE REVIEW}

\subsection{Brand value or brand equity}

Before statistical analysis, it is necessary to make a distinction between the terms brand value and brand equity, which are often used as synonyms in the literature. However, there are some differences.

The concept of brand equity appeared in 1980 (Buzdar et al., 2016). There are different definitions of this term as well as different understandings of the dimensions involved in this concept. Aaker (1991) defines brand equity through four dimensions - brand awareness, associations, perceived quality and brand loyalty. Similarly, Yoo and Donthu (2001) argue that the concept of brand equity includes three dimensions: brand awareness, brand loyalty and perceived quality. Christodoulides and De Chernatony (2010) point to certain perspectives involved in this concept. They make the difference between firm-based brand equity - the financial perspective of brand equity and consumer-based brand equity. Some authors (Shankar et al., 2008) developed a model of brand equity that includes financial and consumer perspective. Those dimensions of brand equity are based on offering value and relative brand importance. The first term refers to the net present value of the products with a recognizable brand. It requires forecasting of revenues and margin ratios. Relative brand importance represents factors of brand image, such as: "brand reputation, brand uniqueness, brand fit, brand associations, brand trust, brand innovation, brand regard, and brand fame" (Shankar et al., 2008).

There is no consensus in the literature on which concept - brand value or brand equity, is a broader concept. Feldwick (1996) considers that there are 3 meanings of brand equity -1) brand description, which is a synonym for the brand image; 2) brand strength, which is a synonym for brand loyalty; and 3) brand value as a monetary category. It can be concluded that according to this approach, brand equity is a broader concept than the concept of brand value since it includes both the monetary value of the brand and the subjective dimensions. Doyle (2001) considers that brand value refers to relationships in value creation and brand equity includes an assessment of value created in this way. Raggio and Leone (2007) point out the brand value to be a broader concept than brand equity. They stated that "brand value represents what the brand means to a focal company". In their opinion, brand value is defined as the sale value of a brand. Brand equity plays an important role because it can affect the higher financial results of brand value since it exists within consumers and can influence their behaviour.

In this research, the term "brand value" will be used, which includes the value from the consumer's point of view, as well as the financial dimension of a brand. 


\subsection{Brand value as a determinant of market performance indicators}

Many studies indicate the impact of brand value on the enterprises's business performance, both financial (Yoo et al., 2000; Kim et al., 2003; Yeung \& Ramasamy, 2008; Mohan \& Sequeira, 2013; Mizik, 2014; Arora \& Chaudhary, 2016; Veljković \& Kaličanin, 2016) and market performance (Barth et al., 1998; Kerin \& Sethuraman, 1998; Yeung \& Ramasamy, 2008; Mohan \& Sequeira, 2013; Hsu et al., 2013; Kirk et al., 2013; Krstić, 2014, p. 196; Mizik, 2014; Arora \& Chaudhary, 2016; Topuz \& Akşit, 2016; Matsumura et al., 2019).

\subsubsection{The link between brand value and key market performance indicators}

Copraro and Srivastava (1997) analysed market to book ratios (MB ratios) of Fortune 500 enterprises and demonstrated that more than $70 \%$ of the market value is based on intangible assets of those enterprises. Research shows that there is a correlation between brand value and stock market value (Bart et al., 2003; Kirk et al., 2012). These authors also point to the impact of brand value on earnings per share (EPS). They claim that brand value provides relevant information about future EPS.

Other studies confirm the strong influence of the brand on the share price (Dutordoir et al., 2015). Topuz and Akşit (2016) concluded that brand value has a positive and statistically significant effect on stock prices. While some other authors (Basgoze et al., 2016) consider that there is an impact of brand value on stock prices; however, this relationship is based on the relatively long run. It means that it takes a long time for the market response to change brand value. Verbeeten and Vijn (2010) claim that the financial value of a brand is a factor that affects the stock prices of an enterprise. Observing data from the 100 Global Brands from 2001 to 2010, Hsu et al. (2013) confirmed a positive correlation between brand value and stock performance (brand value is positively correlated with year-end share price). These analyses, thus, indirectly indicate the influence of brand values on market capitalization. And other authors point to a link between brand value and stock market performance indicators (Yeung \& Ramasamy, 2008). De Mortanges and Van Riel (2003) also concluded that brand value significantly affects enterprise value. When it comes to the direct impact of brand value on market capitalization, Madden et al. (2006) argue that brand value, according to Interbrand methodology, includes $37 \%$ of enterprise's market capitalization, on average. Moreover, other authors emphasize the close connection between brand value and market capitalization (Matsumura et al., 2019).

The impact of brand value on market performance can be observed through the impact of this value on MB ratio, which indicates the relationship between the market value of the enterprise and the enterprise's value according to the financial statements. Lev (1997) suggests that the average MB ratio increased from 2:1 in the late 1980s to 3:1 in the mid-1990s, which is due to the enterprise's intangible resources. He further concludes that in the early 2000s, of every 6 dollars market value, only 1 dollar was shown in the balance sheet, indicating that 5 dollars represent the enterprise's intangible assets (Lev, 2001, p. 8). Kerin and Sethuraman (1998) analysed the relationship between brand value and MB ratio among 50 US consumer goods enterprises. They concluded that enterprises with higher brand value have higher MB ratios. It confirmed a positive relationship between brand value and $\mathrm{MB}$ ratio. This research also led to the conclusion that brand value explains as much as 40 per cent of the difference in MB ratios between enterprises. They showed that the relationship is concave with decreasing returns to scale. 
It indicates that, when the accumulated brand value is small, the increase in the enterprise's MB ratio is higher, but enterprises with high accumulated brand value exhibit a relatively modest increase in MB ratio. Rasti and Gharibvand (2013) claim that the growth of brand value affects book value, which indirectly indicates the impact of brand value growth on $\mathrm{MB}$ ratio, but also on Tobin's $\mathrm{Q}$.

Tobin's Q is the ratio of the company's market value to the replacement cost of assets shown in the balance sheet (Tobin, 1969; 1978). The research of Varaiya et al. (1987) indicates that management creates value for stakeholders if MB ratio of the company is higher than 1. It means, to create value in a company, the market value of the company must be higher than its book value. This indicates an important influence of market value on value creation. This study shows that MB ratio and Tobin's Q are theoretically and empirically, equivalent measures of value creation. Hirschey and Weygandt (1985) concluded that advertising and R\&D expenditure, which are determinants of brand value, have positive and significant effects on Tobin's Q. The study of Berzkalne and Zelgalve (2014), which included 65 Baltic listed companies over the period from 2005 to 2011, indicates that an increase in intangible assets (in which a large part is brand value) leads to increase in Tobin's Q.

The empirical part of the research includes examining the influence of brand value on selected market performance indicators. Therefore, based on the theoretical aspect of these relationships which were given in the previous section, the following research hypothesis will be tested:

Hypothesis H1: Brand value is a significant contributor to market performance.

\section{METHODOLOGY OF RESEARCH}

Data collecting procedure. The study focuses on the impact of brand value on the market performance. To do so, secondary data was used collected from the annual reports (balance sheet, income statement, cash flow statement, statement of changes in equity, notes to the financial statements) of the analysed enterprises. Furthermore, information from the official websites of the sample enterprises is also used to provide the necessary information.

Instruments. The research is based on the data of five indicators: brand value, market capitalization, Tobin's Q, MB ratio and EPS. Data for the brand value is obtained from the brand value evaluation done by Interbrand methodology. Market capitalization is calculated according to Sontakke (2016) by multiplying the market price per share with the total number of outstanding shares. Tobin's Q is calculated as a ratio of market capitalization and total assets (Lindenberg \& Ross, 1981; Perfect \& Wiles, 1994), while $\mathrm{MB}$ ratio is a ratio of market capitalization and net asset of an enterprise (Chen et al., 2005; Yu et al., 2010). Lastly, EPS were measured by dividing net income attributable to shareholders of parent enterprise by the total number of outstanding shares (Balsam \& Lipka, 1998; Slavin, \& Yun, 2001; Arora \& Chaudhary, 2016).

Sample. The sample included top 5 enterprises from high-technology sector, whose brands are on the list of the 100 most valuable brands according to the Interbrand methodology (Krstić \& Popović, 2011), taking into account only top 5 enterprises whose corporate brands are on this list in all years of the analysed eight-year period from 2012 to 2019. These are the following: Apple, Microsoft, IBM, Intel, and Cisco (Table 1). 
Table 1 Enterprises and their brand value for the period 2012-2019, in millions of dollars

\begin{tabular}{lc}
\hline Name & Average brand value \\
\hline Apple & 159,377 \\
Microsoft & 75,072 \\
IBM & 59,295 \\
Intel & 38,264 \\
Cisco & 31,257 \\
\hline
\end{tabular}

Source: Authors' calculations based on the Interbrand survey from 2012 to 2019

Statistical technique. IBM program SPSS (version 26) was employed for analysing the data. Firstly, descriptive analysis was applied to present the main characteristics of the sample. Before conducting parametric tests for measuring relationship and influence of variables, normality tests were applied. Hence, the hypothesis of normally distributed data was not met, all variables have been transformed by taking their logarithm. Secondly, for testing the proposed hypothesis, Pearson's correlation and simple linear regression analysis were applied. For Pearson's correlation coefficient, values of \pm .10 present small, \pm .30 medium effect and \pm .50 large practical effect (Cohen, 1992). The significance level of $\mathrm{p}<.05$ was used as a cut-off point.

Model formulation. The study used simple linear regression models that allowed investigating the impact of brand value on market performance of the top 5 high- technology enterprises. The similar research was conducted by Arora and Chaudhary (2016) where they tested an impact of brand value on the financial performance of Indian banks. In our model, brand value was predictor variable while the other four variables were dependent. Therefore, the following models were defined:

$$
\begin{aligned}
& \text { 1st model Market capitalization }=\alpha+\beta \text { Brand value }+\varepsilon \\
& \text { 2nd model Tobin's } \mathrm{Q}=\alpha+\beta \text { Brand value }+\varepsilon \\
& \text { 3rd model Market to book ratio }=\alpha+\beta \text { Brand value }+\varepsilon \\
& \text { 4th model Earnings per share }=\alpha+\beta \text { Brand value }+\varepsilon
\end{aligned}
$$

\section{THE RESUlTS AND DISCUSSION}

In this section, the findings and discussion on the relationship and influence of enterprise's brand value on market capitalization, Tobin's Q, MB ratio and EPS will be presented.

Table 2 Descriptive statistical analysis of variables

\begin{tabular}{lcrrrr}
\hline Variable & N & Minimum & Maximum & Mean & St. Deviation \\
\hline Brand value (in million \$) & 40 & $27,197.00$ & $234,241.00$ & $72,653.00$ & $53,305.40$ \\
Market capitalization (in million \$) & 40 & $84,626.64$ & $1,105,000.00$ & $345,032.10$ & $281,896.12$ \\
Tobin's Q & 40 & .78 & 3.61 & 1.86 & .69 \\
MB ratio & 40 & 1.65 & 13.40 & 5.46 & 3.09 \\
EPS (in \$) & 40 & 1.20 & 15.64 & 5.56 & 4.42 \\
\hline \multicolumn{5}{l}{ Source: Authors' calculations }
\end{tabular}


Descriptive statistical analysis was used to present minimum, maximum, mean and standard deviation values of researched variables. Table 2 presents the obtained results of the variables analysed in this paper. The average brand value of researched enterprises is 72,653 (St. dev. $=281,896.12$ ) millions of dollars for the eight years, while this value ranges from 27,197 to 234,241 millions of dollars. Market capitalization ranges from $84,626.64$ to $1,105,000.00$ millions of dollars and mean market capitalization was $345,032.10$ (St. dev. $=281,896.12$ ) millions of dollars. Additional data of researched variables are given in Table 2.

In the following table, correlations between brand value and market performance indicators are presented.

Table 3 Correlations between researched variables

\begin{tabular}{|c|c|c|c|c|c|}
\hline & 1 & 2 & 3 & 4 & 5 \\
\hline 1. Brand value & 1 & $.861^{* *}$ & $.635^{* *}$ & $.644^{* *}$ & $.625^{* *}$ \\
\hline 2. Market capitalization & & 1 & $.888^{* *}$ & $.482^{* *}$ & .284 \\
\hline 3. Tobin's $\mathrm{Q}$ & & & 1 & $.379^{*}$ & .069 \\
\hline 4. $\mathrm{MB}$ ratio & & & & 1 & $.742^{* *}$ \\
\hline 5. EPS & & & & & 1 \\
\hline
\end{tabular}

Table 3 shows that among most of researched variables there exists significant and positive correlation. The Pearson correlation coefficient between brand value and market capitalization of $r=0.861$ ( $p<0.05$, large practical effect) indicates that there is a strong and positive relationship between these variables. Furthermore, brand value correlates significantly and positively with Tobin's $\mathrm{Q}(\mathrm{r}=0.635, \mathrm{p}<0.05$, large practical effect), MB ratio $(r=0.644, p<0.05$, large practical effect), and EPS $(r=0.625, p<0.05$, large practical effect). Additionally, this analysis has confirmed that when the value of enterprise's brand increases, firm market performance will increase likewise.

Simple linear regression analysis was conducted to test the proposed research hypothesis stating that brand value is a significant contributor to market performance. The succeeding table gives an overview of the results obtained.

Table 4 Linear regression results

\begin{tabular}{|c|c|c|c|c|}
\hline & $1^{\mathrm{st}}$ model & $2^{\text {nd }}$ model & $3^{\text {rd }}$ model & $4^{\text {th }}$ model \\
\hline Dependent variable & $\begin{array}{c}\text { Market } \\
\text { capitalization }\end{array}$ & Tobin's Q & MB ratio & EPS \\
\hline Brand value $(\beta)$ & $1.036^{* * *}$ & $.392^{* * * *}$ & $.607^{* * * *}$ & $.835^{* * * *}$ \\
\hline $\mathrm{R}$ square & .741 & .403 & .415 & .391 \\
\hline Adjusted $\mathrm{R}^{2}$ & .734 & .388 & .399 & .375 \\
\hline Change $\mathrm{R}^{2}$ & $.741^{* * * *}$ & $.403^{* * *}$ & $.415^{* * *}$ & $.391^{* * *}$ \\
\hline $\mathrm{F}$ & $108.542^{* * * *}$ & $25.685^{* * *}$ & $26.944^{* * *}$ & $24.382^{* * *}$ \\
\hline
\end{tabular}

Table 4 reflects that in the first model brand value has a statistically significant positive influence on market capitalization. $\mathrm{R}$ square $=0.741$ indicates that $74.1 \%$ of the 
variation in market capitalization is explained by brand value. The regression model is statistically significant $(\mathrm{F}=108.542 ; \mathrm{p}<0.05)$. The second model shows that brand value influences $40.3 \%$ of variations in Tobin's Q $(\mathrm{R}$ square $=0.403)$ and the model is statistically significant $(\mathrm{F}=25.685 ; \mathrm{p}<0.05)$. Similarly, in the third model, brand value explains $41.5 \%$ of changes in $\mathrm{MB}$ ratio ( $\mathrm{R}$ square $=0.415$ ). F statistics of this model is 26.944 and statistically significant at the level of 0.000 ( $p<0.05$ ). Lastly, the fourth model points out that brand value explains $39.1 \%$ variations in EPS and F statistics indicates that there is a model fit between the independent and dependent variable $(F=24.382 ; p<0.05)$. In all four models, the beta coefficient is statistically significant $(\mathrm{p}<0.05)$ and has a positive value indicating the positive influence of brand value on researched variables.

Previous results point out that hypothesis $\mathrm{H} 1$ stating that brand value is a significant contributor to market performance is confirmed.

The results of our study are in the line with Matsumura et al. (2019) who have found a significantly high correlation between brand values and market capitalization of Japanese companies $(\mathrm{r}=0.864152, \mathrm{p}<0.01)$. Yang et al. (2018) revealed a positive correlation between brand value and EPS of Taiwan-based businesses. Another study of Eng and Keh (2007) detected that an advertising expense has a positive correlation with brand value. Consequently, brand value has a significant positive correlation with brand sales and brandoperating income and an increase in brand value would lead to an increase in these indicators. They conclude that spending on advertising is beneficial for brand sales and brand profitability, whereas brand value is a good predictor of brand performance.

Arora and Chaudhary (2016) researched the impact of brand value on the financial performance of the top ten Indian banks during the period from 2009 to 2014. According to their results, brand value has a negative impact on indicators such as return on assets, return on investment and return on equity, while it has a positive impact on stock prices. When it comes to EPS, similarly to results of our study, Arora and Chaudhary (2016) showed that brand value has a positive influence on EPS and together with variables age, ownership and size explains $66.1 \%$ of the variability in EPS of Indian banks. They also state that high brand value contributes to the reputation of the bank and motivates investors to buy shares of that bank. In this way, the EPS of banks would increase (Arora \& Chaudhary, 2016 p. 94). Rasti and Gharibvand (2013) explored the effect of brand value on book value, earnings before interest and taxes and dividend yield in Malaysian companies. A positive correlation was found with book value and $40.7 \%$ of the change in book value was explained by brand value. Moreover, earnings before interest and taxes showed a positive correlation with brand value and brand value determines $50 \%$ of fluctuations in earnings before interest and taxes. No significant relationship and influence were found in their study between brand value and dividend yield.

\section{CONCLUSION}

This study researched the relationship between brand value and market performance measured by market capitalization, Tobin's Q, MB ratio and EPS. Moreover, the main objective of the study was to determine the influence that brand value has on the market performance. As the influence of brand value could be significant for one business and its performances, it was important to investigate the extent of that impact using the example of companies from high-technology sector. 
The research was conducted on the sample of five high-technology enterprises rated as valuable brands according to the Interbrand methodology. The results have shown that there is a statistically significant positive relationship between brand value and market performance of enterprises, meaning that when the brand value increases, the market performance would increase accordingly. Moreover, brand value proved to be a significant predictor which positively influences the fluctuations in market performance of enterprise.

This study makes a significant contribution to brand value research by demonstrating that enterprise's primary business benefits from its brand value. Additionally, this study positively answers the question whether it is important for one enterprise from hightechnology sector to make investments in its brand, because this expenditure will generate bigger market capitalization, Tobin's Q, MB ratio and EPS.

There are a few limitations to the study. Firstly, the results cannot be generalized for all enterprises and sectors. Secondly, the research includes data related to one period of time. Therefore, the authors suggest further research in this field that would overcome these shortcomings.

\section{REFERENCES}

Aaker, D. A. (1991). Managing Brand Equity. New York: The Free Press.

Arora, S., \& Chaudhary, N. (2016). Impact of Brand Value on Financial Performance of Banks: An Empirical Study on Indian Banks. Universal Journal of Industrial and Business Management, 4(3), 88-96. https://doi.org/10.13189/ujibm.2016.040302

Balsam, S., \& Lipka, R. (1998). Share Prices and Alternative Measures of Earnings per Share. Accounting Horizons, 12(3), 234-249.

Bart, M. E., Clement, M. B., Foster, G., \& Kasznik, R. (2003). Brand values and capital market valuation. In: Hand, J. \& Lev, B. (Eds.), Intangible assets: values, measures and risk (pp. 153-184). New York: Oxford University Press.

Barth, M. E., Clement, M. B., Foster, G., \& Kasznik, R. (1998). Brand Values and Capital Market Valuation. Review of Accounting Studies, 3, 41-68. https://doi.org/10.1023/A:1009620132177

Basgoze, P., Yildiz, Y., \& Camgoz, S. M. (2016). Effect of brand value announcements on stock returns: empirical evidence from Turkey. Journal of Business Economics and Management, 17(6), 1252-1269. https://doi.org/10.3846/16111699.2016.1153517

Berzkalne, I., \& Zelgalve, E. (2014). Intellectual capital and company value. Procedia - Social and Behavioral Sciences, 110, 887-896. https://doi.org/10.1016/j.sbspro.2013.12.934

Blackett, T. (1991). The Valuation of Brands. Marketing Intelligence \& Planning, 9(1), 27-35. https://doi.org/10.1108/02634509110135442

Brand Finance (2000). Brand Valuation: Measuring and Leveraging your Brand, Retrieved from: http://www.markenlexikon.com/texte/brandfinance_brand_valuation_leverage_may_2000.pdf, Accessed on:_February 10, 2020

Buzdar, M. F., Janjua, S. Y., \& Khurshid, M. A. (2016). Customer-based brand equity and firms' performance in the telecom industry. International Journal of Services and Operations Management, 25(3), https://doi.org/10. 1504/IJSOM.2016.079516

Chen, M., Cheng, S., \& Yuchang, H. (2005). An empirical investigation of the relationship between intellectual capital and firms' market value and financial performance. Journal of Intellectual Capital, 6(2), 159-176. https://doi.org/10.1108/14691930510592771

Christodoulides, G., \& De Chernatony, L. (2010). Consumer-based brand equity conceptualisation and measurement: a literature review. International Journal of Market Research, 52(1), 43-66. https://doi.org/ $10.2501 / \mathrm{S} 1470785310201053$

Cohen, J. (1992). Quantitative methods in psychology: A power primer. Psychological Bulletin, 112(1), 153159. https://doi.org/10.1037/0033-2909.112.1.155

Copraro, A. J., \& Srivastava, R. K. (1997). How do reputations affect corporate performance?: Has the influence of financial performance on reputation measures been overstated?. Corporate Reputation Review, 1(1), 86-92. http://dx.doi.org/ 10.1057/palgrave.crr.1540023 
Davidson, H. (1998). The next generation of brand measurement. The Journal of Brand Management, 5(6), 430-439. https://doi.org/10.1057/bm.1998.33

De Mortanges, C. P., \& Van Riel, A. (2003). Brand equity and shareholder value. European Management Journal, 21(4), 521-527. http://dx.doi.org/doi:10.1016/S0263-2373(03)00076-8

Doyle, P. (2001). Shareholder-value-based brand strategies. Journal of Brand Management, 9(1), 20-30. https://doi.org/10.1057/palgrave.bm.2540049

Drucker, P. (1994). The theory of business. Harvard Business Review, 72(5), 95-104.

Dutordoir, M., Verbeeten, F. H. M., \& De Bejier, D. (2015). Stock price reactions to brand value announcements: Magnitude and moderators. International Journal of Research in Marketing, 32(1), 34-47. https://doi.org/10.1016/j.ijresmar.2014.08.001

Eng, L. L., \& Keh, T. H. (2007). The Effects of Advertising and Brand Value on Future Operating and Market Performance. Journal of Advertising, 36(4), 91-100. https://doi.org/10.2753/JOA0091-3367360407

Feldwick, P. (1996). Do we really need 'Brand Equity?. The Journal of Brand Management, 4(1), 9-28. https://doi.org/10.1057//bm.1996.23

Hsu, F. J., Wang, T. Y. \& Chang, M. Y. (2013). The Impact of Brand Value on Financial Performance. Advances in Management \& Applied Economics, 3(6), 129-141.

Interbrand (2012). Best brands, Retrieved from: https://www.interbrand.com/best-brands/best-globalbrands/2012/ranking/, Accessed on: March 20, 2019.

Interbrand (2013). Best brands, Retrieved from: https://www.interbrand.com/best-brands/best-globalbrands/2013/ranking, Accessed on: March 20, 2019.

Interbrand (2014). Best brands, Retrieved from: https://www.interbrand.com/best-brands/best-globalbrands/2014/ranking, Accessed on: March 20, 2019.

Interbrand (2015). Best brands, Retrieved from: https://www.interbrand.com/best-brands/best-globalbrands/2015/ranking, Accessed on: March 20, 2019.

Interbrand (2016). Best brands, Retrieved from: https://www.interbrand.com/best-brands/best-globalbrands/2016/ranking, Accessed on: March 20, 2019.

Interbrand (2017). Best brands, Retrieved from: https://www.interbrand.com/best-brands/best-globalbrands/2017/ranking, Accessed on: March 20, 2019.

Interbrand (2018). Best brands, Retrieved from: https://www.interbrand.com/best-brands/best-globalbrands/2018/ranking, Accessed on: March 20, 2019.

Interbrand (2019). Best brands, Retrieved from: https://www.interbrand.com/best-brands/best-globalbrands/2019/ranking, Accessed on: February 10, 2020.

Kapferer, J. N. (2012). The New Strategic Brand Management: Advanced Insights and Strategic Thinking. 5th edition, London: Kogan-Page.

Kerin, R. A., \& Sethuraman, R. (1998). Exploring the brand value - Shareholder value nexus for consumer goods companies. Journal of the Academy of Marketing Science, 26(4), 260-273. https://doi.org/10.1177/ 0092070398264001

Kim, H. B., Kim, W. G., \& An, J. A. (2003). The Effect of Consumer-Based Brand Equity on Firm's Financial Performance. Journal of Consumer Marketing, 20(4), 335-351. http://dx.doi.org/10.1108/07363760310483694

Kirk, C. P., Ray, I., \& Wilson, B. (2013). The impact of brand value on firm valuation: The moderating influence of firm type. Journal of Brand Management, 20(6), 488-500. https://doi.org/10.1057/bm.2012.55

Krstić, B., \& Bonić, Lj. (2016). EIC: A new tool for intellectual capital performance measurement. Prague economic papers, 25(6), 723-741. https://doi.org/10.18267/j.pep. 586

Krstić, B. \& Popović, A. (2011). Analiza Interbrand, Brandz i Brand Asset Valuator metodologija za vrednovanje marke [Analysis of the Interbrand, Brandz and Brand Asset Valuator methodologies for brand valuation]. Marketing, 42(4), 237-256.

Krstić, B., Đukić, S., \& Popović, A. (2014). Vrednovanje marke kao ključne intelektualne imovine iz perspektive potrošača [Valuation of the brand as a key intellectual asset from a consumer perspective]. Marketing, 45(1), 14-28.

Lev, B. (1997). The old rules no longer apply: intellectual capital measurement. Forbes Magazine, 72(13), 34-38.

Lev, B. (2001). Intangibles: Management, Measurement, and Reporting. Washington, D.C.: Brookings Institution Press.

Lindenberg, E. B., \& Ross, S. A. (1981). Tobin's q ratio and industrial organization. Journal of Business, 54(1), 1-32. https://doi.org/10.1086/296120

Madden, T. J., Fehle, F., \& Fournier, S. (2006). Brands matter: An empirical demonstration of the creation of shareholder value through branding. Journal of the Academy of Marketing Science, 34(2), 224-235. https://doi.org/10.1177/0092070305283356 
Matsumura, H., Ueda, T., \& Sagane, Y. (2019). Data on the correlations among brand value, market capitalization, and consolidated overseas sales ratios of Japanese companies. Data in Brief, 23, 1-6. https://doi.org/10.1016/j.dib.2019.103808

Mizik, N. (2014). Assessing the Total Financial Performance Impact of Brand Equity with Limited Time- Series Data. Journal of Marketing Research, 51(6), 691-706. https://doi.org/10.1509/jmr.13.0431

Mohan, B. C., \& Sequeira, A. H. (2013). Exploring the Interlinkages between Brand Equity and Business Performance - Towards a Conceptual Framework. Indian Journal of Marketing, 43(2), 5-10. https://doi.org/10.2139/ssrn.2133940

Perfect, S. B., \& Wiles, K. W. (1994). Alternative constructions of Tobin's q: An empirical comparison. Journal of Empirical Finance, 1(3) 313-341. https://doi.org/10.1016/0927-5398(94)90007-8

Popović, A., Krstić, B., \& Milovanović, G. (2015). Merenje finansijske vrednosti marke kao nematerijalne imovine preduzeća [Measuring the financial value of a brand as an intangible asset of a company]. Marketing, 46(1), 13-25.

Raggio, R. D., \& Leone, R. P. (2007). The Theoretical Separation Of Brand Equity And Brand Value: Managerial Implications For Strategic Planning. Journal of Brand Management, 14(5), 380-395. https://doi.org/10.1057/palgrave.bm.2550078.

Rasti, P., \& Gharibvand, S. (2013). The Influence of Brand Value on Selected Malasyian's Companies Book Value and Shareholders. Review of Contemporary Business Research, 2(1), 12-19.

Seetharaman, A., Bin Mohd Nadzir, Z. A., \& Gunalan, S. (2001). A conceptual study on brand valuation. Journal of Product \& Brand Management, 10(4), 243-256. https://doi.org/10.1108/EUM0000000005674

Shankar, V. Azar, P., \& Fuller, M. (2008). BRAN*EQT: A Multicategory Brand Equity Model and its Application at Allstate. Marketing Science, 27(4), 567-584. https://doi.org/10.1287/mksc.1070.0320

Slavin, N., \& Yun, J. K. (2001). Earnings per Share: A Review of the New Accounting Standard. Journal of Corporate Accounting \& Finance, 12(5), 57-71. https://doi.org/10.1002/jcaf.1009

Sontakke, K. A. (2016). A Study of S\&P BSE Small Cap with Reference to Market Capitalisation and Trading Values. SIES Journal of Management, 12(1), 23-36.

Tobin, J. (1969). A General Equilibrium Approach to Monetary Theory. Journal of Money, Credit, and Banking, 1(1), 15-29. https://doi.org/10.2307/1991374

Tobin, J. (1978). Monetary Policies and the Economy: The Transmission Mechanism?. Southern Economic Journal, 44(3), 421-431. https://doi.org/10.2307/1057201

Topuz, Y. V., \& Akşit, N. (2016). The effect of the brand value on firm value: an empirical implementation on global brands. British Journal of Marketing Studies, 4(1), 21-31.

Varaiya, N., Kerin, R. A., \& Weeks, D. (1987). The Relationship Between Growth, Profitability, and Firm Value?. Strategic Management Journal, 8(5), 487-497. https://doi.org/10.1002/smj.4250080507

Veljković, S., \& Kaličanin, Đ. (2016). Improving business performance through brand management practice. Economic annals, 61(208), 137-167. https://doi.org/10.2298/EKA1608137V

Verbeeten, F. H. M., \& Vijn, P. (2010). Are brand-equity measures associated with business-unit financial performance? Empirical evidence from the Netherlands. Journal of Accounting, Auditing and Finance, 25(4), 645-671. http://dx.doi.org/10.1177/0148558X1002500408

Yang, T. Y., Yang, Y. T., Chen, J. R., \& Lu, C. C. (2018). Correlation between owner brand and firm value Case study on a private brand in Taiwan. Asia Pacific Management Review, 24(3), 232-237. https://doi.org/10.1016/j.apmrv.2018.06.002.

Yeung, M., \& Ramasamy, B. (2008). Brand value and firm performance nexus: Further empirical evidence. Journal of Brand Management, 15(5), 322-335. https://doi.org/10.1057/palgrave.bm.2550092

Yoo, B., \& Donthu, N. (2001). Developing and Validating a Multidimensional Consumerbased Brand Equity Scale. Journal of Business Research, 52(1), 1-14. http://dx.doi.org/10.1016/S0148-2963(99)00098-3

Yoo, B., Donthu, N., \& Lee, S. (2000). An examination of selected marketing mix elements and brand equity. Journal of Academy of Marketing Science, 28(2), 195-211. http://dx.doi.org/10.1177/0092070300282002

Yu, K. Y., Ng, H. T., Wong, W. K., Chu, S. K. W., \& Chan, K. H. (2011). An Empirical Study of the Impact of Intellectual Capital Performance on Business Performance. Journal of Information \& Knowledge Management, 10(01), 11-21. https://doi.org/10.1142/S0219649211002791 


\section{UTICAJ VREDNOSTI MARKE NA INDIKATORE TRŽIŠNIH PERFORMANSI VISOKO-TEHNOLOŠKIH PREDUZEĆA}

Koncept vrednosti marke dobija na značaju tokom 1980-ih, kada je primećena razlika između cene po kojoj se kupuju preduzeća i njihove vrednosti prema bilansu stanja. Vrednost marke može se smatrati nematerijalnom imovinom preduzeća, čiji se uticaj na finansijske i tržišne performanse mora uzeti u obzir. Ovaj rad ispituje odnos između vrednosti marke i odabranih indikatora tržišnih performansi, koristeći korelacionu i regresionu analizu. Analiza se zasniva na podacima Interbranda o vrednosti marke i godišnjim izveštajima odabranih visoko - tehnoloških preduzeća. Uzorak uključuje top 5 preduzeća iz visoko-tehnološkog sektora čiji se korporativni brend nalazi na listi 100 najvrednijih brendova u svim godinama analiziranog osmogodišnjeg perioda (od 2012. do 2019. godine). Istraživanje je pokazalo statistički pozitivan odnos između vrednosti marke $i$ indikatora tržišnih performansi, kao $i$ da vrednost marke pozitivno utiče na performance preduzeća iz ovog sektora. U fokusu ovog rada su sledeći indikatori tržišnih performansi: tržišna kapitalizacija, Tobin-ov Q, racio tržišne i knjigovodstvene vrednosti $i$ neto dobit po akciji. Rad doprinosi polju istraživanja upravljanja vrednošću marke $i$ naglašava važnost ulaganja preduzeća u process korporativnog brendiranja.

Ključne reči: vrednost marke, tržišne performanse, tržišna kapitalizacija, Tobin-ov Q, racio tržišne $i$ knjigovodstvene vrednosti, neto dobit po akciji 